Volume 3 Issue 1, March 2019: pp. 67-84. Copyright (c) 2019 HOLREV. Faculty of Law, Halu Oleo University, Kendari, Southeast Sulawesi, Indonesia. ISSN: 2548-1762 | e-ISSN: 2548-1754. Open Access at: http://ojs.uho.ac.id/index.php/holrev/

\title{
Harmonisasi Pengaturan Lembaga Perlindungan Hak Asasi Manusia di Era Globalisasi
}

\author{
Harmonization of Setting Protection Institutions \\ Human Rights in the Era of Globalization
}

\author{
Khalid \\ Fakultas Syari'ah dan Hukum Universitas Islam Negeri Sumatera Utara \\ E-mail: khalid.mhum@gmail.com
}

\begin{abstract}
Protection of human rights for citizens cannot only by ratifying the regulations governing the rights of citizens in various laws and regulations to answer the demands of globalization, but the most important thing then is political will and consistency in carrying out these articles at the level the behavior of the nation and state, and this cannot be separated from the necessity for the existence of State Institutions that maintain, carry out and oversee the realization of the recognition, protection and enforcement of these human rights. This realization can be pursued by harmonizing and strengthening human rights institutions in the constitution to beeffective and independent.
\end{abstract}

Keyword: arrangements; institutions; human rights.

\begin{abstract}
Abstrak: Perlindungan hak asasi manusia bagi warga negara tidak dapat hanya dengan meratifikasi pengaturan yang mengatur hak-hak asasi warga negara dalam berbagai peraturan perundang-undangan untuk menyahuti tuntutan globalisasi, namun yang terpenting kemudian adalah political will dan konsistensi menjalankan pasal-pasal tersebut dalam tataran perilaku berbangsa dan bernegara, dan ini tidak bisa dilepaskan keharusan adanya Lembaga Negara yang menjaga, menjalankan dan mengawal terwujudnya pengakuan, perlindungan dan penegakkan HAM tersebut. Perwujudan ini dapat diupayakan dengan melakukan harmonisasi dan penguatan kelembagaan HAM dalam konstitusi agar efektif dan independen.
\end{abstract}

Kata kunci: pengaturan; lembaga; hak asasi manusia.

\section{PENDAHULUAN}

Globalisasi adalah suatu proses sosial dan budaya yang dimulai dengan berinteraksinya suatu bangsa dengan bangsa lain. Globalisasi dapat didefinisikan sebagai suatu kondisi 
saling tergantung dalam jaringan internasional meliputi transportasi, distribusi, komunikasi, dan ekonomi yang melampaui garis batas teritorial negara. ${ }^{1}$

Proses globalisasi yang bergulir pada tahun 80-an, bukan saja masalah kehidupan ekonomi, tetapi telah melanda dalam globalisasi politik, hankam, iptek, pendidikan, sosial budaya, dan hukum. Globalisasi di bidang politik tidak terlepas dari pergerakan tentang Hak Asasi Manusia (HAM), transparansi, dan demokratisasi. Adanya globalisasi dalam pergerakan HAM, maka Indonesia harus menggabungkan instrumen-instrumen HAM internasional yang diakui oleh negara-negara PBB, ke dalam hukum positif nasional sesuai dengan kebudayaan bangsa Indonesia.² Negara Indonesia sebagai negara demokratis, negara hukum, dan negara yang menjunjung tinggi nilai-nilai HAM yang kemudian tertuang dalam Pembukaan Undang-Undang Dasar Negara Republik Indonesia (UUD NRI 1945), Pasal 27 Ayat (1), Pasal 27 Ayat (2), Pasal 28, Pasal 29 Ayat (2), dan Pasal 31.

Pada masa pemerintahan orde baru, demokrasi belum berjalan dengan baik, terlihat dari tidak adanya keinginan yang kuat untuk mengubah UUD 1945, terkhusus pada penambahan dan penguatan pengaturan HAM dalam UUD 1945 tersebut. Namun, masa pemerintahan Orde Baru tersebut untuk menjawab globalisasi di bidang HAM dengan menyahuti Piagam PBB dan Deklarasi Universal HAM PBB dengan menetapkan beberapa peraturan, di antaranya: (1). Undang-Undang Nomor 7 Tahun 1984 tentang Pengesahan Konvensi mengenai Penghapusan Segala Bentuk Diskriminasi Terhadap Wanita; (2). Keputusan Presiden Nomor 36 Tahun 1990 tentang Pengesahan Hak-hak Anak; dan (3). Keputusan Presiden Nomor 50 Tahun 1993 tentang Komisi Nasional HAM.

Maka, bersamaan dengan pergantian pemerintahan orde baru ke orde reformasi adalah lahirnya Ketetapan MPR RI No. XVII/MPR/1998 tentang HAM. ${ }^{3}$ Sejalan dengan tuntutan reformasi dan globalisasi, maka di era tersebut baru dimungkinkan melakukan amandemen terhadap UUD NRI 1945 mengenai HAM pada Bab tersendiri yakni Bab XA tentang Hak Asasi Manusia, memuat sepuluh (10) pasal mulai dari Pasal 28 sampai Pasal 28J. Perumusan tentang HAM memang belum mencakup pengertian yang esensial mengenai tanggung jawab (kewajiban) asasi manusia. Di samping itu, perumusan HAM itu juga sebagian mengundang ragam pertanyaan, di antaranya, pertama, yakni tidak adanya

1 Jamal Wiwoho, Globalisasi, Surakarta, 2012, www.jamalwiwoho.com/materi-kuliah/strata-3, diakses pada Tanggal 22 Januari 2015, hlm. 2.

2 Muladi, Hak Asasi Manusia: Hakekat, Konsep dan Implikasinya Dalam Perspektfi Hukum dan Masyarakat, Bandung: Refika Aditama, 2009, hlm. 6.

3 Antonius Sujata, Reformasi dalam Penegakan Hukum, Jakarta: Djambatan, 2000, hlm. 51. 
lembaga negara yang lahir dalam perumusan perubahan konstitusi, padahal sudah diatur dengan bab tersendiri yaitu Bab XA Hak Asasi Manusia, yang lazimnya dalam UUD 1945 setiap pengaturan dengan "bab" melahirkan kelembagaan yang mengaturnya. Kedua, mengenai Pasal 28 I ayat (1) UUD 1945 berkenaan dengan pemberlakuan undang-undang yang berlaku surut.

Begitu pentingnya pengaturan HAM yang disadari bahwa diperlukan diikuti dengan adanya lembaga yang menangani edukasi dan penegakan hukum permasalahanpermasalahan HAM di Indonesia, sehingga muncullah Komnas HAM yang diatur dengan Keputusan Presiden Nomor 50 Tahun 1993 tentang Komisi Nasional HAM, yang dikuatkan dengan Undang-Undang Nomor 39 Tahun 1999 tentang HAM. Setelah itu lahir pula Komnas Anti Kekerasan Terhadap Perempuan melalui Keputusan Presiden Nomor 181 Tahun 1998, serta Peraturan Presiden No. 65 Tahun 2005. Selanjutnya lahir pula Komisi Perlindungan Anak, yang diatur dengan Keputusan Presiden Nomor 36 Tahun 1990, Jo. Nomor 77 Tahun 2003 tentang Komisi Perlindungan Anak Indonesia, yang kemudian diperkuat dengan Undang-Undang Nomor 35 Tahun 2014 tentang Perubahan Atas Undang-Undang Nomor 23 Tahun 2002 tentang Perlindungan Anak. Selanjutnya lahir pula Lembaga Perlindungan Saksi dan Korban, serta Ombudsman Republik Indonesia.

Beberapa kelembagaan ini menjadi perhatian penulis, karena kelembagaan/komisi ini yang memiliki kewenangan yang sama di bidang perlindungan dan penegakan HAM, letak perbedaannya hanya pada kekhususan kewenangan antara Komnas HAM yang memiliki fungsi secara umum dan menangani hak asasi berat, sedangkan Komnas Perempuan pada kekerasan terhadap perempuan, dan Komisi Perlindungan Anak Indonesia pada kekerasan terhadap anak. Serta adanya jaminan perlindungan terhadap saksi dan korban pada LPSK, dan layanan baik dan berkualitas terhadap publik dari pemerintah pada Ombudsman Republik Indonesia. Beberapa komisi ini memiliki fungsi dan kewenangan yang muaranya adalah memberikan edukasi, perlindungan, dan penegakan hak asasi manusia di Indonesia. Untuk itu Penulis akan menguraikan peraturan-peraturan HAM yang telah ditetapkan, dan perlunya harmonisasi lembaga/institusi yang telah dibentuk dalam kerangka penegakkan HAM di Indonesia yang kredibel, terpercaya dan mandiri. 


\section{METODE PENELITIAN}

Jenis penelitian/pendekatan yang digunakan oleh penulis adalah penelitian hukum normatif empiris. Penelitian hukum normatif menurut Peter Mahmud Marzuki ${ }^{4}$ yaitu penelitian hukum yang dilakukan dengan pendekatan undang-undang (statute approach), pendekatan kasus (case approach), pendekatan historis (historical approach), pendekatan komparatif (comparative approach), dan pendekatan konseptual (conceptual approach). Sedangkan normatif empiris, ${ }^{5}$ yakni penelitian yuridis dilakukan dengan cara meneliti bahan pustaka yang merupakan data sekunder dan juga disebut penelitian kepustakaan. Penelitian hukum empiris dilakukan dengan cara meneliti di lapangan yang merupakan data primer.

\section{ANALISIS DAN PEMBAHASAN}

\section{Disharmonisasi Pengaturan Lembaga Perlindungan Hak Asasi Manusia di Indonesia}

Menurut ajaran umum, salah satu dari syarat atau negara hukum ialah adanya jaminan atas hak-hak asasi manusia. Jaminan ini harus terbaca atau tertafsir dari konstitusi yang berlaku, apakah ia konstitusi tertulis maupun yang tak tertulis, setidak-tidaknya termaklumi dari praktik-praktik hukum yang berlaku sehari-hari. Sebagai hak, maka hakhak asasi ini tak lepas dari soal kebebasan dan kewajiban, baik di pihak pemegang kekuasaan maupun pihak pendukung hak asasi itu sendiri. ${ }^{6}$

Sebelum perubahan UUD 1945 HAM yang termuat dalam UUD 1945 terbatas jumlahnya dan dirumuskan secara singkat, sebab naskah konstitusi tersebut dibuat pada waktu zaman kemerdekaan. Mengenai hal ini, Soekarno pada waktu itu menyatakan: "jikalau kita betul-betul hendak mendasarkan negara kita kepada paham kekeluargaan, paham tolong menolong, paham gotong royong dan keadilan sosial, enyahkanlah tiap-tiap pikiran (tentang HAM), tiap paham individualisme dan liberalisme dari padanya". Sebaliknya Hatta mengatakan bahwa walaupun yang dibentuk itu negara kekeluargaan, tetapi masih perlu ditetapkan beberapa hak dari warga negara, jangan sampai timbul negara kekuasaan (machsstaat). ${ }^{7}$ Melalui Perubahan Kedua UUD NRI 1945 pada Tahun

Peter Mahmud Marzuki, Penelitian Hukum, Jakarta: Kencana Prenada Media Group, 2005, hlm. 93.

5 Ronny Hanitijo Soemitro, Metode Penelitian Hukum dan Jurimetri, Jakarta: Ghalia Indonesia, 1990, hlm. 36.

6 Padmo Wahyono, Masalah Ketatanegaraan Indonesia Dewasa Ini, Ghalia Jakarta: Indonesia, 1985, hlm. 323.

7 Moh. Mahfud MD, Dasar dan Struktur Ketatanegaraan Indonesia, Jakarta: Rineka Cipta, 2001, hlm. 138. 
2000 terhadap pengakuan dan perlindungan HAM diatur dalam Bab tersendiri yakni Bab XA tentang Hak Asasi Manusia, yang memuat sebanyak sepuluh (10) pasal. ${ }^{8}$

Di era reformasi sampai sekarang negara Indonesia telah banyak menetapkan peraturan perundang-undangan berperspektif HAM dan ratifikasi instrumen HAM internasional, yaitu: ${ }^{9}$

a. Keppres Nomor 129 Tahun 1998 tentang Komisi Nasional Anti Kekerasan Terhadap Perempuan;

b. Instruksi Presiden Nomor 26 Tahun 1998 tentang Menghentikan Penggunaan Istilah Pribumi dan Non Pribumi dalam Semua Perumusan dan Penyelenggaraan Kebijakan Perencanaan Program ataupun Pelaksanaan Kegiatan Penyelenggaraan Pemerintahan;

c. Undang-Undang Nomor 5 Tahun 1998 tentang Pengesahan Konvensi Menentang Penyiksaan dan Perlakuan atau Penghukuman Lain yang Kejam, Tidak Manusiawi atau Merendahkan;

d. Keppres Nomor 181Tahun 1998 tentang Komisi Nasional Anti Kekerasan Terhadap Perempuan;

e. Undang-Undang Nomor 9 Tahun 1998 tentang Kemerdekaan Menyampaikan Pendapat di Muka Umum;

f. Undang-Undang Nomor 39 Tahun 1999 tentang Hak Asasi Manusia;

g. Undang-Undang Nomor 26 Tahun 2000 tentang Pengadilan HAM;

h. Konvensi ILO Nomor 87 Tahun 1948, diratifikasi berdasarkan Keppres Nomor 83 Tahun 1998 tentang Kebebasan Berserikat dan Perlindungan Hak untuk Berorganisasi;

i. Konvensi ILO Nomor 105 Tahun 1957, diratifikasi berdasarkan UndangUndang Nomor 19 Tahun 1999 tentang Penghapusan Kerja Paksa;

j. Konvensi ILO Nomor 111 Tahun 1958, diratifikasi berdasarkan UndangUndang Nomor 21 Tahun 1999 tentang Larangan Diskriminasi dalam Pekerjaan dan Jabatan;

k. Konvensi ILO Nomor 138 Tahun 1973, diratifikasi berdasarkan UndangUndang Nomor 20 Tahun 1999 tentang Usia Minimum Untuk Diperbolehkan Bekerja;

l. Konvensi ILO Nomor 182 Tahun 1999, diratifikasi berdasarkan UndangUndang Nomor 1 Tahun 2000 tentang Pelarangan dan Tindakan Segera Penghapusan Bentuk-bentuk Pekerjaan Terburuk Untuk Anak;

m. Konvensi ILO Nomor 88 Tahun 1948, diratifikasi berdasarkan Keppres Nomor 36 Tahun 2002 tentang Lembaga Pelayanan Penempatan Tenaga Kerja.

Kemudian tambahan peraturan perundang-undangan terbaru yang belum disebutkan di atas, yakni:

a. Undang-Undang Nomor 23 Tahun 2004 tentang Penghapusan Kekerasan Dalam rumah Tangga;

8 Lihat UUD NRI 1945 Pasal 28A, Pasal 28B ayat (1) dan (2), Pasal 28C ayat (1) dan (2), Pasal 28D ayat (1), (2), (3) dan (4), Pasal 28E ayat (1) dan (2), Pasal 28F, Pasal 28G ayat (1) dan (2), Pasal 28H ayat (1), (2), (3) dan (4), Pasal 28I ayat (1), (2), (3), (4) dan (5), Pasal 28J ayat (1) dan (2).

9 Muladi, Op.cit., hlm. 5. 
b. Undang-Undang Nomor 13 Tahun 2006 tentang Perlindungan Saksi dan Korban;

c. Undang-Undang Nomor 40 Tahun 2008 tentang Penghapusan Diskriminasi Ras dan Etnis;

d. Undang-Undang Nomor 11 Tahun 2012 tentang Sistem Peradilan Anak;

e. Undang-Undang Nomor 35 Tahun 2014 tentang Perubahan atas UndangUndang Nomor 23 Tahun 2002 tentang Perlindungan Anak.

Begitu banyaknya peraturan perundang-undangan yang telah mengatur tentang HAM. Tapi, yang paling penting adalah eksistensi institusi penegak HAM itu harus diberdayakan dan diperkuat agar dapat mewujudkan perlindungan dan penegakkan HAM di Indonesia. Selanjutnya di bawah ini akan penulis sebutkan lembaga/institusi perlindungan dan penegakan HAM yang telah ada di Indonesia.

a. Komnas HAM. Kelembagaan Komnas HAM sesungguhnya telah dibentuk Tahun 1993 melalui Keppres Nomor 50 Tahun 1993, tetapi setelah Orde Baru jatuh, lembaga ini mendapat landasan hukum yang lebih kuat sekaligus perluasan dan penguatan tugas dan kewenangan melalui Undang-Undang Nomor 39 tentang HAM sebagaimana disebutkan dalam Prinsip-Prinsip Paris. Dengan undangundang ini, Komnas HAM ditempatkan sebagai salah satu lembaga negara setingkat dengan lembaga negara lainnya yang berfungsi melaksanakan pengkajian, penelitian, penyuluhan, pemantauan, dan mediasi HAM. Selain itu wewenang Komnas HAM dalam melakukan fungsi pemantauan terhadap kasus pelanggaran HAM juga diperluas dengan adanya kewenangan untuk memanggil saksi secara paksa (subpoena). ${ }^{10}$

b. Komisi Nasional Anti Kekerasan Terhadap Perempuan. Komisi Nasional Anti Kekerasan Terhadap Perempuan (Komnas Perempuan) adalah lembaga independen yang dibentuk berdasarkan Keppres Nomor 181 Tahun 1998, kemudian diperkuat dengan Peraturan Presiden Nomor 65 Tahun 2005. Komnas Perempuan lahir dari tuntutan masyarakat sipil, terutama kaum perempuan kepada pemerintah untuk mewujudkan tanggung jawab negara dalam menanggapi dan menangani kekerasan terhadap perempuan. Tuntutan tersebut berakar dari tragedi kekerasan seksual yang dialami terutama etnis Tionghoa dalam kerusuhan Mei 1998 di berbagai kota besar di Indonesia. ${ }^{11}$

\footnotetext{
10 Suparman Marzuki, Tragedi Politik Hukum HAM, Yogyakarta: Pustaka Pelajar dan Pusham UII, 2011 hlm. 229. Lihat juga, Pasal 95 Undang-Undang Nomor 39 tahun 1999 tentang HAM.

11 Ibid., hal. 230. Lihat juga dalam Tujuan Komnas Perempuan ini berdasarkan PP. No. 65 Tahun 2005.
} 
c. Komisi Perlindungan Anak Indonesia (KPAI). Lembaga ini merupakan lembaga independen yang dibentuk berdasarkan Undang-Undang Nomor 23 Tahun 2002 tentang Perlindungan Anak. Lembaga ini dibentuk untuk merespons berbagai laporan adanya kekerasan, penelantaran dan belum terpenuhinya hak-hak dasar anak Indonesia. Banyaknya kasus pekerja anak, anak-anak dalam area konflik, pelibatan anak dalam konflik senjata seperti yang terjadi di Aceh, tingginya angka putus sekolah, busung lapar, perkawinan di bawah umur, trafficking, dan sebagainya telah mendorong masyarakat internasional untuk menekan pemerintah Indonesia agar membentuk lembaga khusus yang bertugas memantau kondisi perlindungan anak di Indonesia. ${ }^{12}$

Lembaga ini akan memberikan perlindungan khusus kepada anak dalam situasi darurat, anak yang berhadapan dengan hukum, anak dari kelompok minoritas dan terisolasi, anak yang dieksploitasi secara ekonomi dan/seksual, anak yang diperdagangkan, anak yang menjadi korban penyalahgunaan narkotika, alkohol, psikotropika, dan zat adiktif lainnya (napza), anak korban penculikan, penjualan, perdagangan, anak korban kekerasan baik fisik dan/atau mental, anak yang menyandang cacat, dan anak korban perlakuan salah dan penelantaran. ${ }^{13}$

d. Lembaga Perlindungan Saksi dan Korban (LPSK). Setelah keluarnya UndangUndang Nomor 13 Tahun 2006 tentang Perlindungan Saksi dan Korban. Pemerintah dan DPR baru membentuk Lembaga Perlindungan Saksi dan Korban pada Tahun 2008, dua tahun setelah undang-undang ini diberlakukan dengan mengesahkan 7 (tujuh) anggota LPSK pada 15 Juli 2008. Dengan adanya LPSK ini diharapkan mekanisme perlindungan saksi dan korban sudah bisa dilakukan sebagaimana diatur dalam undang-undang ini. ${ }^{14}$

e. Ombudsman Republik Indonesia. Sebelumnya lembaga ini bernama Komisi Ombudsman Nasional (KON), kemudian setelah lahir Undang-Undang Nomor 37 Tahun 2008 tentang Ombudsman Republik Indonesia, ${ }^{15}$ mendapatkan

12 Rahayu, Hukum Hak Asasi Manusia (HAM), Semarang: Badan Penerbit Universitas Diponegoro, 2012, hlm. 179-180.

13 Suparman Marzuki, Tragedi Politik..Op.cit., hlm. 265-266.

14 Ibid., hlm. 277. Lihat juga UU. No. 13 tahun 2008 tentang Perlindungan Saksi dan Korban Pasal 1 angka 3.

15 Ombudsman Republik Indonesia memiliki keanggotaan 9 (sembilan) orang, dalam UU. No. 37 Tahun 2008 Pasal 11 (1). 
penguatan dalam undang-undang ini menjadi Ombudsman Republik Indonesia (ORI). Tugas dan kewenangan ORI sebagaimana umumnya Ombudsman di negara-negara lain pada dasarnya melaksanakan dan memastikan dihormatinya, dipenuhi, dan dilindunginya hak-hak asasi manusia, khususnya warga negara untuk mendapatkan pelayanan umum yang baik dan bermutu dari penyelenggara negara. Pelayanan publik yang baik adalah salah satu HAM yang masuk dalam lingkup hak-hak sipil.

f. Lembaga HAM Internasional (Dewan HAM PBB). Universal Declaration of Human Rights (Deklarasi Universal tentang Hak-hak Asasi Manusia disetujui dan diumumkan oleh Resolusi Majelis Umum PBB 217 A (III) Tanggal 10 Desember 1948.16 Majelis Umum PBB (General Assembly) merupakan lembaga tertinggi dalam sistem PBB yang merupakan subyek hukum internasional. Di bawah sistem PBB inilah terdapat berbagai macam lembaga yang bekerja untuk HAM. Semuanya di bawah Dewan Hak Asasi Manusia (Human Rights Council) berdasarkan Resolusi Majelis Umum 60/251 tanggal 15 Maret 2006 menggantikan Komisi HAM PBB yang dibubarkan pada 16 Juni 2006. Selanjutnya di bawah Dewan Hak Asasi Manusia inilah dibentuk komisi-komisi HAM, yakni: ${ }^{17}$

1) Komite HAM (Human Rights Committee). Komite HAM ini bertugas menerima dan membahas laporan negara atas pelaksanaan kovenan internasional tentang hak sipil dan politik negaranya masing-masing. Juga berwenang menerima pengaduan individu atas pelanggaran HAM yang ia terima. Anggota komite ini berjumlah 18 orang.

2) Komite Hak Ekonomi, Sosial dan Budaya (Committee for Economic, Social and Cultural Rights). Komite ini memiliki anggota berjumlah 18 orang, dengan tugas menerima laporan negara atas pelaksanaan kovenan hak ekonomi, sosial dan budaya oleh negara yang telah meratifikasi.

3) Komite atas Penghapusan Diskriminasi Rasial (Committee on the Elimination of Racial Discrimination). Komite yang juga beranggotakan 18 orang ini bertugas menerima laporan negara atas pelaksanaan konvensi,

16 Peter Baehr, Pieter van Dijk, Adnan Buyung Nasution, Leo Zwaak, Instrumen Internasional Pokok Hak-hak Asasi Manusia, Jakarta: Yayasan Obor Indonesia, 2001, hlm. 280.

17 Rahayu, Op.cit., hlm. 135-136. 
menerima pengaduan negara atas tindakan negara lain yang mendiskriminasikan warganya, serta menerima pengaduan individu atas tindakan diskriminatif dari negara yang ia terima.

4) Komite tentang Penghapusan Diskriminasi terhadap Perempuan (Committee on the Elimination of Discrimination against Women). Komite ini beranggotakan 23 orang, bertugas menerima laporan negara dan pengaduan individual, namun komite ini dapat diberi wewenang untuk melakukan penyelidikan atas pengaduan terjadinya diskriminasi terhadap perempuan, jika negara yang bersangkutan memberi mandat.

5) Komite Menentang Penyiksaan (Committee against Torture). Komite ini dibentuk berdasarkan konvensi menentang penyiksaan dan perlakuan atau penghukuman lain yang kejam, tidak manusiawi atau merendahkan martabat, beranggotakan 10 orang. Tugas, menerima laporan dari negara dan pengaduan individual. Serta, kewenangan melakukan penyelidikan atas inisiatifnya sendiri ketika ada pelanggaran terhadap konvensi.

6) Komite tentang Hak Anak (Committee on the Rights of Child). Komite ini dibentuk berdasarkan konvensi tentang hak anak yang terdiri dari 10 orang, bertugas menerima laporan negara atas pelaksanaan konvensi dan memberikan rekomendasi hal-hal yang perlu dilakukan oleh negara yang bersangkutan.

7) Komite Pekerja Migran (Migrant Worker's Committee). Komite ini merupakan yang termuda, karena dibentuk berdasar Konvensi Internasional tentang Perlindungan Hak Semua Pekerja Migran dan Anggota Keluarganya, yang mulai berlaku pada 14 September 2006. Komite ini bertugas menerima laporan negara dan pengaduan individual.

\section{Upaya Harmonisasi Pengaturan Lembaga Perlindungan Hak Asasi Manusia di Era Globalisasi}

Pembangunan hukum mempunyai makna yang lebih menyeluruh dan mendasar dibandingkan dengan istilah pembinaan hukum atau pembaharuan hukum. Pembinaan hukum lebih mengacu pada efisiensi, dalam arti meningkatkan efisiensi hukum. Pembaharuan hukum mengandung pengertian menyusun suatu tata hukum untuk menyesuaikan dengan perubahan masyarakat. Oleh karena itu, pembangunan hukum 
tidak hanya tertuju pada aturan atau substansi hukum, tetapi juga pada struktur atau kelembagaan hukum dan pada budaya hukum masyarakat. ${ }^{18}$

Pembangunan hukum diarahkan pada makin terwujudnya sistem hukum nasional yang mantap bersumber pada Dasar Negara Republik Indonesia 1945, yang mencakup pembangunan materi hukum, struktur hukum, termasuk aparat hukum, sarana dan prasarana hukum; perwujudan masyarakat yang mempunyai kesadaran dan budaya hukum yang tinggi dalam rangka mewujudkan negara hukum. ${ }^{19}$ Dalam penegakkan hukum dan pembangunan bangsa menurut Jamal Wiwoho:

a. Hukum dapat digunakan sebagai alat rekayasa sosial dalam membentuk desain pembangunan bangsa;

b. Pembangunan bangsa di masa sekarang dan yang akan datang dapat dilihat dari desain politik hukum yang dibuat oleh negara yang dirumuskan dalam konstitusi, politik legislasi melalui Prolegnas dan desain kebijakan pemerintah dalam menyikapi persoalan bangsa;

c. Dukungan political will pemimpin negeri ini memiliki peran kunci dalam mewujudkan penegakkan hukum. ${ }^{20}$

Penataan pranata hukum dan pelembagaan hukum yang jelas dengan menata komponen tersebut, agar proses pembangunan hukum dapat berjalan selaras dan serasi serta lebih fokus terhadap masalah substansial. Oleh karena itu, perlu ada suatu mekanisme pengintegrasian, bahwa pembangunan hukum harus mencakup (serba meliputi) semua komponen sistem hukum di atas, yang secara simultan berjalan melalui langkah-langkah strategis, mulai dari perencanaan pembuatan aturan (legislation planning), proses pembuatannya (law making procces), sampai kepada penegakan hukum (law enforcement) yang dibangun melalui kesadaran hukum (law awareness). ${ }^{21}$

Konstitusi sebagai wadah yang menampung sesuatu ide, pikiran atau gagasangagasan. Ide tersebut selanjutnya dicantumkan satu persatu sebagai isi konstitusi. Berarti konstitusi merupakan perwujudan cita-cita, misalnya; cita-cita rakyat untuk dilindungi hak-hak asasinya ketika berbenturan dengan kekuasaan pemerintah. ${ }^{22}$ Oleh karena itu, pentingnya ada pengaturan kelembagaan di bidang HAM dalam konstitusi, agar

18 Adi Sulistiyono dan Muhammad Rustamaji, Hukum Ekonomi Sebagai Panglima, Sidoarjo: Masmedia Buana Pustaka, 2009, hlm. 15.

19 Adi Sulistiyono, Materi Matrikulasi T.A. Agustus 2014 Program Doktor Ilmu Hukum, Surakarta: Fakultas Hukum UNS, 2014, hlm. 25.

20 Jamal Wiwoho, Agenda Penegakkan Hukum dan Relevansinya dalam Pembangunan Bangsa, Makalah Seminar Nasional di Fakultas Hukum Unisula, Semarang 22 Januari 2013, www.jamalwiwoho.com/hasilkarya/presentasi-2, diakses pada tanggal 22 Januari 2015, hlm. 16.

21 Muladi, Op.cit., hlm. 33.

22 Didi Nazmi Yunas, Konsepsi Negara Hukum, Padang: Angkasa Raya, 1992, hlm. 50. 
pengakuan dan perlindungan HAM itu tidak menjadi bias oleh kekuasaan negara. Salah satu identitas dari suatu negara hukum adalah adanya jaminan dan perlindungan terhadap hak-hak asasi manusia yang mesti dihormati dan dijunjung tinggi oleh penyelenggara negara beserta segenap warga negaranya.

Perlindungan terhadap HAM adalah tuntutan absolut keadilan karena kondisi sebaliknya, ketidakadilan, tidak dikehendaki. Bukti bagi pernyataan ini adalah lahirnya berbagai gerakan sebagai berikut. Pertama, konstitusionalisasi dan internasionalisasi HAM menentukan aspek hukum substantif bagi ruang lingkup HAM. Kedua, pembentukan institusi dan mekanisme nasional maupun internasional untuk perlindungannya baik yudisial maupun non-yudisial. Ketiga, corrective justice atas ketidakadilan yang ditimbulkan melalui berbagai praktik pelanggaran terhadap HAM baik masa lalu maupun masa kini dalam bentuk responsibility dan liability pelaku individual dan negara. ${ }^{23}$

Konsekuensi pertama dari pengakuan terhadap hak-hak asasi manusia ialah pengertian yang lebih mendalam akan makna demokrasi. HAM membentuk landasan demokrasi. Pada saat membentuk negara, manusia tidak melepaskan hak-hak asasinya, seperti hak untuk menentukan kehidupan sendiri. ${ }^{24}$ Dalam tatanan negara hukum yang dinamis, negara ikut terlibat secara aktif dalam usaha menciptakan kesejahteraan masyarakat. Di satu pihak negara dituntut untuk senantiasa melindungi hak-hak asasi, namun di pihak lain diharuskan menyelenggarakan kepentingan umum yang berupa kesejahteraan masyarakat.

Studi tentang konstitusi dalam masa-masa perubahan ketatanegaraan menunjukkan bahwa berbagai bentuk transisi akan menimbulkan watak konstitusi yang bermacam. Menurut Ruti G. Teitel, ${ }^{25}$ sebagaimana yang dikutip Adi Sulistiyono, ada tiga kemungkinan watak konstitusi tersebut, yaitu, pertama, konstitusi kritis. Dalam hal ini konstitusi yang baru secara eksplisit merekonstruksi tatanan ketatanegaraan yang dikaitkan dengan ketidakadilan. Kedua, konstitusi restoratif. Watak ini muncul jika konstitusi baru berfungsi untuk mengembalikan tatanan normatif sebelum rezim yang

23 Titon Slamet Kurnia, Konstitusi HAM, Undang-Undang Dasar Negara Republik Indonesia Tahun 1945 dan Mahkamah Konstitusi RI, Yogyakarta: Pustaka Pelajar, 2014, hlm. 35.

24 Adnan Buyung Nasution, Aspirasi Pemerintahan Konstitusional di Indonesia, Studi Sosio-Legal atas Konstituante 1956-1959, Jakarta: Pustaka Utama Grafiti, 2001, hlm. 176.

25 Adi Sulistiyono, Negara Hukum: Kekuasaan, Konsep, dan Paradigma Moral, Surakarta: LPP UNS, UPT UNS, UNS Press, 2008, hlm. 23-25. 
ditumbangkan. Ketiga, konstitusi residual. Watak ini lahir jika konstitusi baru merupakan kelanjutan dari pemerintahan sebelumnya.

Komnas HAM (termasuk juga Komnas Perempuan, Komisi Perlindungan Anak Indonesia, Lembaga Perlindungan Saksi dan Korban, dan Ombudsman Republik Indonesia) dibentuk berdasarkan Keputusan Presiden, Peraturan Presiden, dan UndangUndang. Namun demikian, lembaga ini dapat dikatakan merupakan salah satu lembaga negara yang memiliki constitutional importance yang sama dengan kejaksaan dan kepolisian. Mengapa demikian? Karena di setiap negara konstitusional, jaminan hak asasi manusia dalam Undang-Undang Dasar dianggap sebagai sesuatu yang mutlak adanya. Bahkan jaminan konstitusional hak asasi manusia itu merupakan ciri pokok negara hukum atau paham negara demokrasi konstitusional (constitutional democracy). ${ }^{26}$

Lembaga negara ada yang dibentuk berdasarkan atau karena diberi kekuasaan oleh Undang-Undang Dasar, Undang-Undang, dan bahkan ada pula yang hanya dibentuk berdasarkan Keputusan Presiden. ${ }^{27}$ Independensi kelembagaan, ditandai beberapa hal: (a) Otonomi organisasional maupun administratifnya; (b) Otonomi anggaran atau budget; (c) Persyaratan profesional maupun etik keanggotaannya; (d) Kepastian masa jabatan; (e) Kewenangan setiap aparatur membuat keputusan yang bersifat merdeka dan mengikat; (f) Ketentuan tentang konflik kepentingan dan pedoman tingkah laku yang berstandar tinggi; dan (g) Akses publik terhadap informasi. ${ }^{28}$ Oleh sebab itu, pembenahan institusi dimaksud diharapkan tercipta situasi yang kondusif yang mendukung institusi dan manusia pelaksana hukum menegakkan hukum progresif dalam melindungi HAM. ${ }^{29}$ Terkait dengan akses publik, bilamana merujuk pada pengalaman Amerika Serikat menegaskan relasi antara doktrin kepercayaan publik (public trust doctrine) dengan hadirnya lembaga-lembaga negara federal. Given the Reagan Administration's environmental policies and the uncertainty of its successor's policies, it appears that now, more than ever, new legal tools are necessary to protect public land against politically

26 Jimly Asshiddiqie, Perkembangan dan Konsolidasi Lembaga Negara Pasca Reformasi, Jakarta: Sinar Grafika, 2012, hlm. 210.

27 Ibid., hlm. 37.

28 Jamal Wiwoho, Op.cit., hlm. 17.

29 Suparman Marzuki, Pengadilan HAM di Indonesia; Melanggengkan Impunity, Jakarta: Penerbit Erlangga, 2012, hlm. 255. 
motivated federal agencies. The public trust doctrine, if clarified and strengthened, may be of future use against federal agency actions. ${ }^{30}$

Evaluasi terhadap beberapa kelembagaan/ komisi yang ada ini hemat penulis perlu dilakukan, paling tidak ada 2 (dua) hal yang perlu disoroti, pertama, problem efektivitas dari fungsi atau kewenangan masing-masing komisi yang muaranya sama yakni menangani masalah penanganan penegakan hak asasi manusia. Hanya saja dibedakan antara perempuan dan anak-anak, padahal dalam konstitusi sudah ada pengaturan tentang perlindungan bagi keluarga, perempuan dan anak-anak.

Sebagai institusi normatif, hukum akan kehilangan fungsinya jika melalui kewenangan yang dimilikinya tidak dapat menundukkan perilaku masyarakat di bawah otoritasnya. ${ }^{31}$ Selanjutnya, terkait dengan problem efisiensi komisi yang ada mulai menginflasi, menjamurnya komisi negara tidak berbanding lurus dengan berkurangnya problem kebangsaan. Ada beberapa kesamaan kewenangan dari beberapa komisi atau lembaga ini, yakni pertama; sama-sama memiliki kewenangan melaksanakan pengkajian, penelitian, penyuluhan, pemantauan, dan mediasi hak asasi manusia. Kedua, sama-sama mengembangkan kondisi yang kondusif bagi pelaksanaan hak asasi manusia sesuai dengan Pancasila dan UUD 1945. Ketiga, meningkatkan perlindungan dan penegakan hak asasi manusia guna berkembangnya pribadi manusia Indonesia seutuhnya.

Selanjutnya dari kelembagaan, beberapa komisi ini diakui sebagai lembaga yang mandiri dan independen, tetapi belum diatur secara mandiri oleh undang-undang tentang kekhususan pengaturan kelembagaan ini. Ada 2 (dua) dimensi yang kemudian melemahkan kemandirian beberapa kelembagaan/komisi ini, pertama; independensi pengaturan kelembagaan, Komnas HAM hanya diatur dalam undang-undang tentang HAM, bukan atau belum ada pengaturan secara khusus dengan undang-undang tentang Komnas HAM. Demikian pula dengan Komnas Perempuan dan KPAI, Komnas Perempuan hanya diatur dengan Peraturan Presiden, sedangkan KPAI diatur dalam undang-undang tentang perlindungan anak. Kedua; independensi kewenangan kelembagaan, Komnas HAM menyampaikan rekomendasi atas suatu kasus pelanggaran hak asasi manusia kepada Presiden dan DPR. Sedangkan Komnas Perempuan dan KPAI menyampaikan kepada Presiden, demikian juga halnya dengan LPSK dan ORI.

\footnotetext{
30 Susan D. Baer, "The Public Trust Doctrine A Tool to Make Federal Administrative Agencies Increase Protection of Public Law and Its Resources", Boston College Environmental Affairs Law Review Vol. 15, 1988, hlm. 386.

31 Adi Sulistiyono dan Muhammad Rustamaji, Op.cit., hlm. 107.
} 
Menurut penulis harmonisasi kelembagaan/komisi di bidang HAM di Indonesia perlu segera dilakukan mengingat wacana akan dilakukannya perubahan kelima terhadap UUD 1945. Hal ini untuk menyinergikan lembaga/komisi yang telah ada dengan jalan melebur dan menguatkannya dalam UUD 1945 sebagai lembaga negara yang mandiri. Sejalan dengan hal tersebut dalam pandangan Backer, ${ }^{32}$ mengatakan these interactions affect not only national legal systems of substantive laws, increasingly, interaction has led to harmonization of constitutional norm. Maka dibutuhkan harmonisasi HAM dalam sistem hukum nasional dari beberapa ketentuan, interaksi dan institusi yang ada dalam sebuah konstitusi. Sebagaimana ditegaskan oleh Backer di bawah ini:

A foundational principle in international human rights law is that the role of international enforcement organs is subsidiary to the efforts of national institutions. Although international courts and quasi-judicial bodies may be empowered by treaty to enforce international human rights law, the first and foremost authorities to deal with claims of human rights abuse are the national authorities. ${ }^{33}$

Mengingat kewenangan Komnas HAM selaku penyelidik pro-yustisia dalam kasus pelanggaran HAM yang berat bersinggungan dengan institusi negara lainnya, seperti DPR, Kejaksaan Agung, dan Mahkamah Agung, maka jika terjadi sengketa dengan lembaga negara tersebut berkaitan dengan kewenangan masing-masing, tidak bisa diselesaikan oleh Mahkamah Konstitusi, karena Komnas HAM tidak disebut sebagai lembaga negara seperti halnya Komisi Yudisial atau Mahkamah Konstitusi. ${ }^{34}$ Hal ini untuk memenuhi salah satu unsur sistem hukum, yakni adanya lembaga-lembaga hukum, yang mengatur di dalamnya: struktur organisasinya, kewenangannya, proses dan prosedur, serta mekanisme kerja. ${ }^{35}$ Pengaturan kelembagaan yang efektif dan efisien tentunya berdasarkan empat pengaturan kelembagaan tersebut; pertama, kejelasan organisasinya. Hal ini belum tercantum dengan tegas terhadap Komnas HAM, Komnas Perempuan, dan KPAI. Kedua, kewenangannya, yakni kewenangan yang diberikan dengan tegas di dalam konstitusi atau undang-undang, atau kewenangan atributif dari pemerintah. Hal ini dapat dilihat dari masing-masing kewenangan Komnas HAM, Komnas Perempuan dan KPAI yang belum menunjukkan kemandirian kewenangan. Ketiga, proses dan prosedur pengangkatan beberapa komisi ini yang juga belum mengindikasikan ketidakberpihakan

\footnotetext{
32 Larry Cata Backer, Harmonizing Law in an Era of Globalization, Convergence, Divergence, and Resistance, Durham, North Carolina: Carolina Academic Press, 2007, hlm. 13.

33 Ibid., hlm. 45.

34 Suparman Marzuki, Politik Hukum Hak Asasi Manusia, Jakarta: Penerbit Erlangga, 2014, hlm. 257.

35 Adi Sulistiyono dan Muhammad Rustamaji, Op.cit., hlm. 13.
} 
dan demokratis (masih dalam kewenangan Presiden). Keempat, mekanisme kerjanya, ini yang menguatkan tidak efektif dan efisiennya karena masing-masing komisi memiliki mekanisme kerja yang relatif sama.

Menurut Jimly Asshiddiqie,36 banyaknya lembaga atau komisi yang dibentuk di Indonesia tumbuh begitu saja bagaikan cendawan di musim hujan. Ketika ide pembaruan kelembagaan diterima sebagai pendapat umum, di mana di semua lini dan semua bidang, orang berusaha untuk menerapkan ide pembentukan lembaga dan organisasi baru itu dengan idealisme, yaitu untuk modernisasi dan pembaruan menuju efisiensi dan efektivitas pelayanan. Hal ini juga sejalan dengan pendapat yang disampaikan oleh Friedman, ${ }^{37}$ bahwa tentang sistem hukum tersebut harus memenuhi; struktur adalah kerangka badannya, institusionalnya, dan substansi tersusun dari peraturanperaturannya, serta kultur adalah elemen sikap dan nilai sosial.

Dimensi pengaturan HAM relatif sudah cukup memenuhi substansi dari pentingnya ada pengaturan perlindungan HAM. Untuk itu penting melebur beberapa komisi ini (Komnas HAM, Komnas Perempuan, KPAI, LPSK, dan ORI) menjadi satu kelembagaan saja yang kemudian dikuatkan dalam UUD 1945. Sehingga akan terwujud harmonisasi dengan lebih efektif dan efisien untuk mengatur mengenai kelembagaan HAM di Indonesia. Kemudian, kelembagaan pada HAM PBB, bahwa semua komite-komite yang ada menjadi satu kesatuan di bawah Dewan Hak Asasi Manusia (Human Rights Council) Majelis Umum PBB. Juga, kelembagaan HAM di Eropa yang khusus untuk melindungi HAM, Majelis Eropa dengan kantor pusat di Strasburg (Perancis) telah membentuk: Komisi Hak Asasi Manusia (European Commission of Human Rights), Mahkamah Hak Asasi Manusia (European Court of Human Rights), dan Panitia para Menteri (Committee of Ministers). ${ }^{38}$

Pada prinsipnya, bila berhasil melalui perdamaian, Komisi Hak Asasi Manusia Eropa meneruskan keputusan tersebut kepada para pihak, yaitu Panitia para Menteri dan Sekjen Majelis Eropa. Sebaliknya bila gagal, para pihak maupun komisi dapat meneruskan kepada Mahkamah. Bila dalam waktu tiga bulan tidak diteruskan kepada Mahkamah, maka Panitia para Menteri mengambil keputusan sendiri. ${ }^{39}$

\footnotetext{
36 Jimly Asshiddieqie, Op.Cit., hlm. 296.

37 Lawrence M. Friedman, Sistem Hukum Perspektif Ilmu Sosial, terjemahan oleh M. Khozim, Bandung: Nusa Media, 2011, hlm, 15-17.

38 A. Masyhur Effendi dan Taufani S. Evandri, HAM dalam Dinamika/Dimensi Hukum, Politik, Ekonomi dan Sosial, Bogor: Ghalia Indonesia, 2010, hlm. 119-120.

39 Ibid., hlm. 120-121.
} 


\section{KESIMPULAN}

Disharmonisasi pengaturan lembaga perlindungan hak asasi manusia di Indonesia dikarenakan terlalu banyaknya lembaga perlindungan hak asasi manusia di Indonesia, sehingga menyebabkan terjadinya tumpang tindih kewenangan dan fungsi masing-masing kelembagaan yang berujung pada tidak efektif dan independennya lembaga hak asasi manusia di Indonesia dalam melaksanakan perlindungan dan penegakan hak asasi manusia.

Upaya harmonisasi pengaturan lembaga perlindungan hak asasi manusia di era globalisasi adalah dengan pembangunan hukum penguatan kelembagaan HAM dalam konstitusi yang perlu terus dilakukan, Lembaga Negara di bidang HAM selayaknya masuk dalam konstitusi agar menjamin terlaksananya pengakuan, perlindungan dan penegakkan HAM yang lebih berwibawa, efektif dan efisien sebagai lembaga negara yang independen, setara dengan lembaga negara lain yang telah diatur dalam UUD 1945. Harmonisasi kelembagaan yang ada di Indonesia perlu dilakukan dengan mengadopsi lembaga HAM internasional, yang menjadikan semua lembaga/komisi yang ada menjadi satu kesatuan (terpusat) pada satu kelembagaan hak asasi manusia.

\section{Daftar Pustaka}

\section{Buku}

Asshiddiqie, Jimly, Perkembangan dan Konsolidasi Lembaga Negara Pasca Reformasi, Jakarta: Sinar Grafika, 2012.

Backer, Larry Cata, Harmonizing Law in an Era of Globalization, Convergence, Divergence, and Resistance, Durham, North Carolina: Carolina Academic Press, 2007.

Baehr, Peter, Pieter van Dijk, Adnan Buyung Nasution, Leo Zwaak, Instrumen Internasional Pokok Hak-hak Asasi Manusia, Jakarta: Yayasan Obor Indonesia, 2001.

Effendi, A. Masyhur, dan Taufani S. Evandri, HAM dalam Dinamika/Dimensi Hukum, Politik, Ekonomi dan Sosial, Bogor: Ghalia Indonesia, 2010.

Kurnia, Titon Slamet, Konstitusi HAM, Undang-Undang Dasar Negara Republik Indonesia Tahun 1945 dan Mahkamah Konstitusi RI, Yogyakarta: Pustaka Pelajar, 2014.

M. Friedman, Lawrence, The Legal System: A Social Science Perspective, Russel Sage Foundation, New York, 1975 (edisi terjemahan) M. Khozim, Sistem Hukum Perspektif Ilmu Sosial, Bandung: Nusa Media, 2011. 
Mahfud MD, Moh, Dasar dan Struktur Ketatanegaraan Indonesia, Jakarta: Rineka Cipta, 2001.

Marzuki, Peter Mahmud, Penelitian Hukum, Jakarta: Kencana Prenada Media Group, 2005.

Muladi, Hak Asasi Manusia: Hakekat, Konsep dan Implikasinya dalam Perspektfi Hukum dan Masyarakat, Bandung: Refika Aditama, 2009.

Nasution, Adnan Buyung, Aspirasi Pemerintahan Konstitusional di Indonesia, Studi SosioLegal atas Konstituante 1956-1959, Jakarta: Pustaka Utama Grafiti, 2001.

Rahayu, Hukum Hak Asasi Manusia (HAM), Semarang: Badan Penerbit Universitas Diponegoro, 2012.

Soemitro, Ronny Hanitijo, Metode Penelitian Hukum dan Jurimetri, Jakarta: Ghalia Indonesia, 1990.

Sujata, Antonius, Reformasi dalam Penegakan Hukum, Jakarta: Djambatan, 2000.

Sulistiyono, Adi, "Globalisasi dan Politik Hukum", dalam Materi Matrikulasi T.A. Agustus 2014 Program Doktor Ilmu Hukum, Surakarta: Fakultas Hukum UNS, 2014.

dan Muhammad Rustamaji, Hukum Ekonomi Sebagai Panglima, Sidoarjo: Masmedia Buana Pustaka, 2009.

Negara Hukum: Kekuasaan, Konsep, dan Paradigma Moral, Surakarta: LPP UNS, UPT UNS, UNS Press, 2008.

Suparman, Marzuki, Pengadilan HAM di Indonesia: Melanggengkan Impunity, Jakarta: Erlangga, 2012.

Politik Hukum Hak Asasi Manusia, Jakarta: Erlangga, 2014. Tragedi Politik Hukum HAM, Yogyakarta: Pustaka Pelajar dan Pusham UII, 2011.

Wahyono, Padmo, Masalah Ketatanegaraan Indonesia Dewasa Ini, Jakarta: Ghalia Indonesia, 1985.

Yunas, Didi Nazmi, Konsepsi Negara Hukum, Padang: Angkasa Raya, 1992.

\section{Jurnal, Makalah dan Website}

Baer, Susan D., “The Public Trust Doctrine A Tool to Make Federal Administrative Agencies Increase Protection of Public Law and Its Resources", Boston College Environmental Affairs Law Review, Volume 15, Article 5, Boston, 1988.

Wiwoho, Jamal, “Agenda Penegakkan Hukum dan Relevansinya dalam Pembangunan Bangsa", Makalah Seminar Nasional di Fakultas Hukum Unisula, Semarang, 22 
Januari 2013, www.jamalwiwoho.com/hasil-karya/presentasi-2, diakses pada tanggal 22 Januari 2015.

, Globalisasi, Surakarta, 2012, www.jamalwiwoho.com/materi-kuliah/strata-3, diakses pada Tanggal 22 Januari 2015.

Peraturan Perundang-undangan

Undang-Undang Dasar Negara Republik Indonesia Tahun 1945

Ketetapan MPR RI No.XVII/MPR/1998 tentang Hak Asasi Manusia.

Undang-Undang Nomor 39 Tahun 1999 tentang Hak Asasi Manusia.

Undang-Undang Nomor 23 Tahun 2003 tentang Perlindungan Anak.

Undang-Undang Nomor 13 Tahun 2006 tentang Perlindungan Saksi dan Korban.

Undang-Undang Nomor 37 Tahun 2008 tentang Ombudsman Republik Indonesia.

Undang-Undang Nomor 40 Tahun 2008 tentang Penghapusan Diskriminasi Ras dan Etnis.

Undang-Undang Nomor 35 Tahun 2014 tentang Perubahan Atas Undang-Undang Nomor

23 Tahun 2002 tentang Perlindungan Anak.

Keputusan Presiden Nomor 50 Tahun 1993 tentang Komisi Nasional Hak Asasi Manusia.

Keputusan Presiden Nomor 181 Tahun 1998 tentang Komnas Anti Kekerasan Terhadap Perempuan.

Keputusan Presiden Nomor 36 Tahun 1990, Jo. Nomor 77 Tahun 2003 tentang Komisi Perlindungan Anak Indonesia.

Peraturan Presiden No. 65 Tahun 2005 tentang Komnas Anti Kekerasan Terhadap Perempuan. 